\title{
ETV5 Gene
}

National Cancer Institute

\section{Source}

National Cancer Institute. ETV5 Gene. NCI Thesaurus. Code C97479.

This gene plays a role in the regulation of gene transcription. 